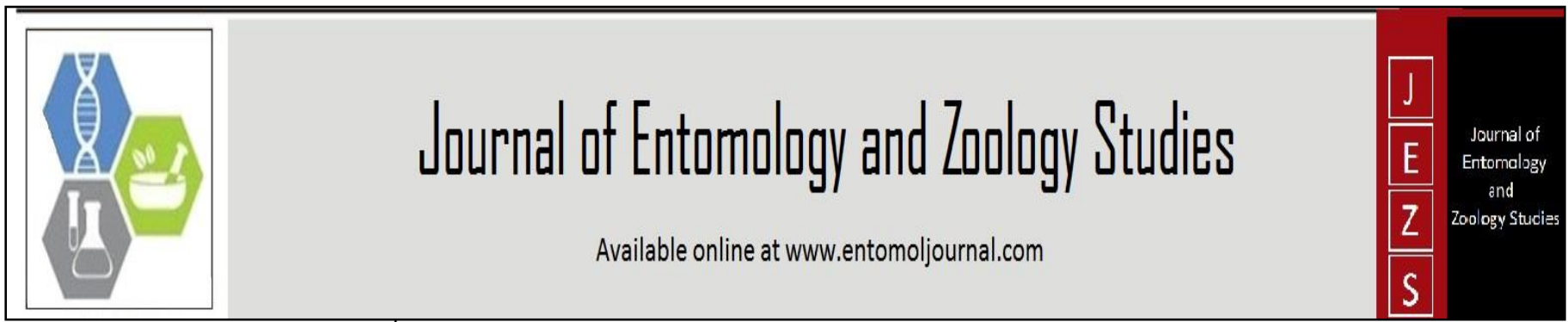

E-ISSN: 2320-7078 P-ISSN: 2349-6800 JEZS 2019; 7(3): 772-774

(C) 2019 JEZS

Received: 19-03-2019

Accepted: 23-04-2019

Mark I Cooper

University Cape Town, South Africa

\section{Quasi-experimental determination of a mass standard in the forest millipede Centrobolus inscriptus}

\title{
Abstract
}

Sexual size dimorphism (SSD) in the diplopod species Centrobolus inscriptus has a positive correlation with body size. Intraspecific intersexual variation in mass was calculated twice in this species (males: $2.48 \pm 0.57 \mathrm{~g} ; 2.00 \pm 0.22 \mathrm{~g}$; females: $2.27 \pm 0.28 \mathrm{~g} ; 2.61 \pm 0.42 \mathrm{~g}$ ) and data sets tested for SSD. Males differed significantly from females in body mass (students $\mathrm{t}$-test: $\mathrm{t}=9.38$, d.f. $=95, p<0.05$ ). This was again found in the larger sample where males and females differed significantly from each other in mass (Wilcoxon matched pairs test: $\mathrm{T}=554, \mathrm{n}=88, \mathrm{P}=0.00$ ). When the two data sets were pooled and the mean's compared, a difference was found $(\mathrm{t}=2.3162, \mathrm{n}=273 ; \mathrm{p}=0.020918)$. It was found males were lighter and have higher reproductive success through female preference for larger males when there was Size assortative mating behaviour. Conformity to the mass standard in sexual selection was suggested. Millipedes may influence concentrations of soil elements through sex-specific difference.

Keywords: Diplopod, lighter, horizontal, mass

\section{Introduction}

Diplopoda are interesting environmental indicators and under-represented in analyses of invertebrate sexual size dimorphism (SSD) which is the condition where the two sexes of the same species exhibit different characteristics beyond the differences in their sexual organs, although common sexual differences are thought to occur in body mass, length, width and leg dimensions of over half the taxa studied ${ }^{[1-15]}$. Worm-like millipedes resemble the majority of invertebrates in SSD is mostly reversed ${ }^{[7,8]}$. Heavier-shorter-wider females are under a type of fecundity selection ${ }^{[4]}$. Larger males have increased reproductive success through female preference for larger size when there is size assortative mating behaviour.

Mass can be a useful standard in millipedes and mass measurements are known for at least 15 taxa (Cooper, unpublished). Although millipedes (Centrobolus fulgidus, Centrobolus richardii and Spinotarsus sp.) influence selected soil elements, the results of millipede these studies have illustrated no major sex-specific differences for individual species ${ }^{[16]}$. Here it is hypothesized and appears in Centrobolus sp. the males are almost always lighter than females and the lighter more slender males are expected to be under a type of sexual selection. Furthermore there appears to be a mass standard in sexual selection, basically implying species-specific mass measurements controlled through sexually selected factors ${ }^{[13]}$. The particular sexual selection is thought to be a female preference for larger male size which operates when there is size-assortative mating behaviour.

In the present communication, SSD in the species Centrobolus inscriptus was investigated and the effect of mass in determining a response in SSD tested. I wished to establish a mass standard in sexual selection of millipedes.

\section{Materials and Methods}

Centrobolus inscriptus (Attems, 1928) millipedes were collected in April 1995 from Zululand (Twin streams farm, Mtunzini) in South Africa, where they occur in indigenous coastal forest $\left(28^{\circ} 59^{\prime} 13.4^{\prime \prime} \mathrm{S}, 31^{\circ} 43^{\prime} 41.3^{\prime \prime} \mathrm{E}\right)$. Live specimens of each sex were transported to the laboratory where conditions were kept under a constant regime of $25^{\circ} \mathrm{C}$ temperature; $70 \%$ relative humidity; 12:12 hrs light-dark cycle. Food was provided in the form of fresh vegetables ad libitum. Individuals had unknown mating histories. Unisex groups were housed in plastic containers containing moist vermiculite $( \pm 5 \mathrm{~cm}$ deep). 


\subsection{Mass measurements}

Centrobolus inscriptus mass (accurate to $0.01 \mathrm{~g}$ ) was obtained using a Mettler balance calibrated accurate to $0.01 \mathrm{~g}$. Mass measurements were recorded after performing mating experiments. Individuals were placed in a $13 \mathrm{~cm}$ plastic container which had been zeroed on the balance and the measurement recorded. Measurements were taken from Centrobolus inscriptus and the basic descriptive figures were statistically tested males versus females using a parametric followed by a non-parametric test.

\subsection{Statistical tests}

Statistical analyses were performed using (1) Statgraphics (version 6.0) and (2) Statistica (A 1997 version). Morphometric (mass) data were tested for normality using a Kolmogorov-Smirnov test before comparing male and female mass data from two sets of mating experiments using a Student's t-test and Wilcoxon matched pairs test.

\section{Results}

Table 1: Male and female mass in Centrobolus inscriptus. Values given are averages $(\mu)$ and Standard Deviation (SD) with sample sizes $(\mathrm{N})$ on the right.

\begin{tabular}{|c|c|c|c|}
\hline \multirow{3}{*}{ Species } & Male & Female & N \\
\cline { 2 - 3 } & Mass & Mass & \\
\cline { 2 - 3 } & $(\boldsymbol{\mu} ;$ SD $)$ & $(\boldsymbol{\mu} ; \mathbf{S D})$ & \\
\hline \multirow{2}{*}{ C. inscriptus } & $2.48 \pm 0.57$ & $2.27 \pm 0.28$ & 88,88 \\
\cline { 2 - 3 } & $2.00 \pm 0.22$ & $2.61 \pm 0.42$ & 56,41 \\
\hline
\end{tabular}

Males differed significantly from females in body mass (students t-test: $\mathrm{t}=9.38$, d.f. $=95, p<0.05$ ). This was again found in the larger sample where males and females differed significantly from each other in mass (Wilcoxon matched pairs test: $\mathrm{T}=554, \mathrm{n}=88, \mathrm{P}=0.00)$. When the two data sets were pooled and the mean mass compared, the difference was found and illustrated $(\mathrm{t}=2.3162, \mathrm{n}=273 ; \mathrm{p}=0.020918$; see Table 1). Overall male $C$. inscriptus were significantly lighter than females in mass measurements.

\section{Discussion}

The mass in the males in Centrobolus inscriptus extends on studies which shows the size of Juliformia "has two main components: body diameter and number of" rings and provides a standard in millipede mass ${ }^{[12]}$. This supports the idea of slenderness in juliform male millipedes ${ }^{[2]}$. Correlates of Juliform size include oxygen consumption, copulation duration, energetic cost of copulation, precipitation, sexual dimorphism and temperature $[7,8,10,11,14]$. Size criteria are useful for determining species of Juliformia diplopods and research has illustrated mass in size data sets can always determine sex in Centrobolus. The two measurements pooled thus conform to the mass standard in sexual selection ${ }^{[13]}$. $C$. inscriptus males have a greater body length and are slender and lighter than females and body mass which is positively related to copulation duration and SSD ${ }^{[6-8]}$.

The mass in the males in Centrobolus inscriptus extends on studies which illustrated no major sex-specific differences for individual species ${ }^{[16]}$. It can be hypothesized that millipedes influence concentrations of soil elements through sex-specific differential effects and patterns related to composition and species richness may reflect sex-specific differences because "the rate at which soil elements increase in the microcosms suggests that millipede activity may accelerate the release of elements in areas undergoing vegetation development on coastal dune forests ${ }^{[16]}$.

The mass in the males in Centrobolus inscriptus is similar to studies on sexual selection on mass have shown in mice heavier females produced more offspring, while males of intermediate mass have higher fitness suggesting an aspect of natural selection acts to decrease body mass with the upper and lower boundaries of male mass constrained by sexual selection ${ }^{[15]}$. Sexual selection for body mass also reduces litter size in mammals ${ }^{[3]}$. Because copulation duration correlates with female size in millipedes litter size will predictably increase.

\section{Conclusion}

Size of Centrobolus inscriptus conforms to a mass standard in sexual selection. Body mass in males is a reproductive parameter co-varying with copulation duration and order of mating. Millipedes may influence concentrations of soil elements through sex-specific differential effects.

\section{References}

1. Adolph SC, Geber MA. Mate-Guarding, Mating Success and Body Size in the Tropical Millipede 'Nyssodesmus Pythos' (Peters) Polydesmida: Platyrhacidae). The Southwestern Naturalist. 1995; 40(1):56-61.

2. Akkari N, Enghoff H. Copulatory-copulatory male succession and male slenderness in Ommatiulus sempervirilis $\mathrm{n}$. sp., a new insular millipede from Tunisia (Diplopoda: Julida: Julidae). Journal of Zoological Systematics and Evolutionary Research. 2011; 49(4):285291.

3. Carranza J. Evolution of Litter Size in Mammals. The American Naturalist 1996; 148(1):81-100.

4. Cooper MI. Heavier-shorter-wider females in the millipede Centrobolus inscriptus (Attems). Journal of Entomology and Zoology Studies. 2016; 4(2):509-510.

5. Cooper MI. The influence of male body mass on copulation duration in Centrobolus inscriptus (Attems). Journal of Entomology and Zoology Studies. 2016; 4(6):804-805.

6. Cooper MI. The effect of female body width on copulation duration in Centrobolus inscriptus (Attems). Journal of Entomology and Zoology Studies. 2017; 5(1):732-733.

7. Cooper MI. Allometry of copulation in worm-like millipedes. Journal of Entomology and Zoology Studies. 2017; 5(3):1720-1722.

8. Cooper MI. Copulation and sexual size dimorphism in worm-like millipedes. Journal of Entomology and Zoology Studies. 2017; 5(3):1264-1266.

9. David JF. Size criteria for the distinction between Cylindroiulus londinensis (Leach) and Cylindroiulus caeruleocinctus (Wood) (Diplopoda: Julidae), Journal of Natural History. 1995; 29(4):983-991.

10. Dwarakanath SK. The influence of body size and temperature upon the oxygen consumption in the millipede, Spirostreptus asthenes (Pocock). Comparative Biochemistry and Physiology Part A: Physiology. 1971; 38(2):351-358.

11. Echeverría KS, Ignacio C, Bueno-Villegas J. Relationship between millipede body size (Polydesmida: Xystodemidae: Rhysodesmus) and altitude, latitude, precipitation and temperature. $16^{\text {th }}$ International Conference of Myriapodology, 2014. 
12. Enghoff $H$. The Size of a Millipede. Berichte der naturhistorisch-medizinischen Vereins Innsbruck, Supplement, 1992, 10.

13. Lorber N. Conformity to the mass standard in sexual selection. Social Behavior and Personality: An international journal. 1980; 8:65-74.

14. Penteado CHS, Hebling-Beraldo MJA, Mendes EG. Oxygen consumption related to size and sex in the tropical millipede Pseudonannolene tricolor (Diplopoda, Spirostreptida), Comparative Biochemistry and Physiology Part A: Physiology. 1991; 98(2):265-269.

15. Ruff JS, Cornwall DH, Cauceglia JW, Nelson AC, Gaukler SM, Meagher S et al. Sexual selection constrains the body mass of male but not female mice. Ecology and Evolution. 2017; 7(4):1271-1275.

16. Smit AM, Van Aarde RJ. The influence of millipedes on selected soil elements: a microcosm study on three species occurring on coastal sand dunes. Functional Ecology. 2001; 15(1):51-59. 